\title{
Magnesium and Calcium Contents of Fish and Squid Tissues*
}

\author{
Takeshi TAGUCHI, Kōsaku SuzuKI, and Isami OSAKABE** \\ (Received January 4, 1969)
}

The frequent occurrence of struvite in marine canned foods has been known for many years and its appearance is undesirable commercially.

It is well known that magnesium and calcium form a part of struvite. In order to clarify the mechanism of struvite formation, it would be necessary to know the distribution of the metal ions in the body. From this point of view, however, very little work has been carried out.

The present paper deals with magnesium and calcium contents of the fish and squid tissues, liberation of the both metals from the muscle proteins during storage, and intracellular distribution of magnesium in the muscle.

\section{Materials and Methods}

Fish and squid tissues. The muscle, heart, liver and kidney of freshly landed fish, such as mackerel, Pneumatophorus japonicus japonicus (HouTtuYn), jack mackerel, Trachurus japonicus (TEMMINCK \& SCHLEgel), barracuda, Sphyraena japonica CuVIER, flatfish, Limanda herzensteini JORDAN \& SNYDER, skipjack, Katsuwonus pelamis (LinNAEUS) and carp, $C y$ prinus carpio Linnaeus, and squid, Todarodes pacificus SteEnstrup, were used.

Measurement of magnesium and calcium contents. Magnesium and calcium contents were measured by the atomic absorption spectrophotometer (139-0420 Hitachi-type). The Ca-Mg hollow cathode was set to generate light of a magnesium resonance radiation at $2852 \AA$ and a calcium resonance radiation at $4227 \AA$. The pressure of air and acetylene was adjusted to $1.5 \mathrm{~kg} / \mathrm{cm}^{2}$ and $0.4 \mathrm{~kg} / \mathrm{cm}^{2}$, respectively, according to the method of WILLIS $^{1}$. The test solution was made up to a suitable volume ( 50 or $200 \mathrm{ml}$ ) with water containing $0.3 \% \mathrm{SrCl}_{2}$, after digestion of each tissue $(2-5 \mathrm{~g})$ in perchloric acid. In the present experiments, above $95 \%$ of standard magnesium sulfate and calcium chloride added to samples before digestion were recovered.

Determination of liberated magnesium and calcium. The muscle stored at $4^{\circ} \mathrm{C}$ for various lengths of time was homogenized with three volumes of cold water for 2 min in a Waring Blender. The homogenate was treated with $10 \%$ trichloroacetic acid and filtered.

* Biochemical and Crystallographical Studies on Struvite of Marine Canned Foods and Prevention of its Formation-VIII.

** Tokyo University of Fisheries, Konan-4, Minato-ku, Tokyo (田口武・鈴本康策・小坂部型, 東京水産 大学). 
The liberated amounts were expressed as the relative amount in the filtrate to the total amount present in the muscle homogenate.

Centrifugal fractionation of the muscle. The experimental procedures are outlined in Fig. 1. The homogenate from carp muscle was dialysed against 50 volumes of distilled

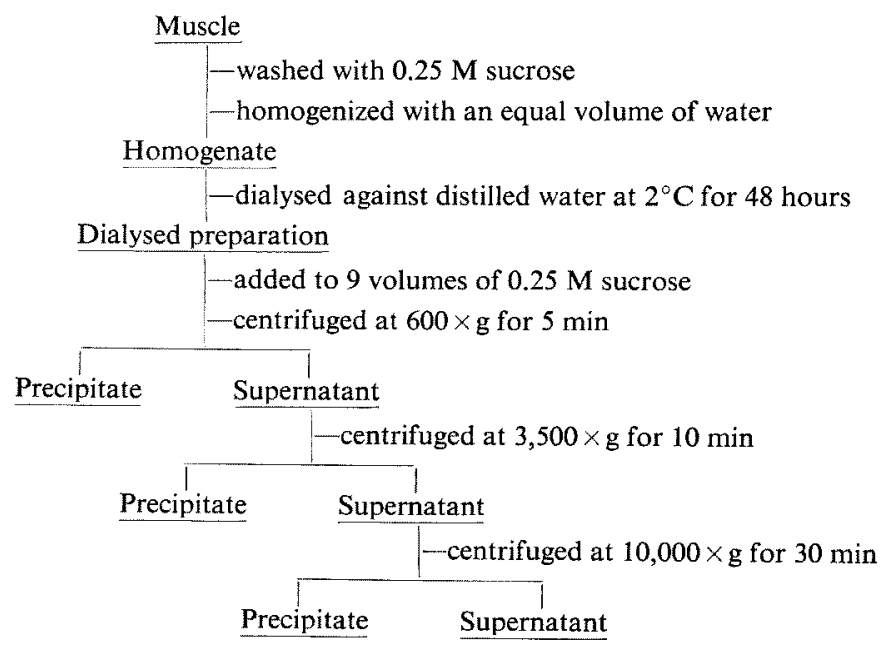

Fig. 1. Centrifugal fractionation of the carp muscle.

water at $2^{\circ} \mathrm{C}$ until no more free magnesium could be found in the diffusate. The water was renewed every $8 \mathrm{hr}$. The resulting preparation was subjected to the centrifugal fractionation according to the procedure of CHAPPEL et $a l^{2}$. The magnesium content of each fraction was expressed as $\mu \mathrm{g}$ per $\mathrm{mg}$ of protein- $\mathrm{N}$ determined by the semimicro-Kjeldahl method.

\section{Results and Discussion}

Magnesium and calcium contents of fish and squid tissues. The results obtained on the various tissues of fish are summarized in Table 1. Though the amounts of magnesium and calcium were variable according to the species of fish examined, they were found to exist in all the tissues tested, and the dorsal muscle showed the highest content of magnesium in all the species.

The content of magnesium and calcium in the liver and muscle of squid is given in Table 2. The magnesium content of muscle was higher than that of liver.

Liberation of magnesium and calcium from the muscle proteins. In general, a large portion of the metal ions has been shown to exist as a type of chelate complexes in living organisms. The liberation of metal ions from the muscle proteins would be important in food technology, especially in understanding of the mechanism of struvite occurrence in canned foods. For these reasons, the rate of liberation of magnesium and calcium from 
Table 1. Magnesium and calcium contents of fish tissues ( $\mathrm{mg} \%$ ).

\begin{tabular}{|c|c|c|c|c|c|c|c|c|c|c|c|c|c|c|}
\hline \multirow{3}{*}{ Species } & \multirow{3}{*}{$\begin{array}{l}\text { Date of } \\
\text { capture }\end{array}$} & \multirow{3}{*}{$\begin{array}{c}\text { Body } \\
\text { weight } \\
\text { (g) }\end{array}$} & \multicolumn{6}{|c|}{ Muscle } & \multirow{2}{*}{\multicolumn{2}{|c|}{ Heart }} & \multirow{2}{*}{\multicolumn{2}{|c|}{ Liver }} & \multirow{2}{*}{\multicolumn{2}{|c|}{ Kidney }} \\
\hline & & & \multicolumn{2}{|c|}{ Dorsal } & \multicolumn{2}{|c|}{ Abdomen } & \multicolumn{2}{|c|}{ Dark } & & & & & & \\
\hline & & & $\mathrm{Mg}$ & $\mathrm{Ca}$ & $\mathrm{Mg}$ & $\mathrm{Ca}$ & $\mathrm{Mg}$ & $\mathrm{Ca}$ & $\mathrm{Mg}$ & $\mathrm{Ca}$ & $\mathrm{Mg}$ & $\mathrm{Ca}$ & $\mathrm{Mg}$ & $\mathrm{Ca}$ \\
\hline Mackerel & Jul. 10 & 353 & 34.9 & 14.1 & $\ldots$ & - & $23.3^{\prime}$ & 27.1 & 16.7 & 15.4 & 21.7 & 21.4 & 22.3 & 36.3 \\
\hline Jack mackerel & Jul. $\quad 10$ & 89 & 27.8 & 22.6 & - & - & - & - & 15.5 & 26.0 & 18.7 & 32.1 & - & - \\
\hline Barracuda & Aug. 6 & 82 & 34.6 & 18.2 & 27.7 & 23.7 & - & - & 21.0 & 13.9 & 18.4 & 14.9 & 16.1 & 24.3 \\
\hline Flatfish & Aug. 6 & 152 & 23.9 & 16.9 & - & - & - & - & 14.1 & 25.8 & 9.9 & 25.1 & 14.7 & 20.4 \\
\hline Skipjack & Aug. 6 & 2325 & 41.0 & 18.0 & 35.1 & 36.3 & 26.4 & 32.1 & 21.5 & 13.1 & 25.4 & 17.7 & 26.0 & 30.2 \\
\hline Carp & Sep. 2 & 408 & 30.2 & 11.9 & 29.9 & 11.2 & 15.2 & 4.0 & 18.1 & 20.3 & 21.5 & 13.9 & 14.5 & 6.3 \\
\hline
\end{tabular}

Table 2. Magnesium and calcium contents of squid tissues (mg \%).

\begin{tabular}{ccc}
\hline Tissues & $\mathrm{Mg}$ & $\mathrm{Ca}$ \\
\hline Muscle hood & 27.7 & 27.9 \\
mantle & 38.1 & 17.6 \\
arm & 341 & 229 \\
Liver & 27.2 & 17.2 \\
\hline
\end{tabular}

the muscle proteins during cold storage was determined. Typical examples are shown in Figs. 2 and 3.

As shown in the figures, magnesium was liberated fairly rapidly during storage, suggesting that the chelating agency of muscle proteins for magnesium becomes extremely weak with the storage time, as compared with that for calcium.

As noted by OSAKABE et al. ${ }^{3}$, the struvite of marine canned foods contains commonly magnesium ammonium phosphate as the major component and only a little amount of calcium. If the struvite occurrence is dependent upon the release of these metal ions from the muscle proteins, this phenomenon would be accelerated by lowering of chelating agency of muscle proteins. Further, OSAKABE et al. ${ }^{4 \sim 61}$ have stated that the occurrence of struvite in the marine canned foods is directly related to the freshness of its material. Their infor-

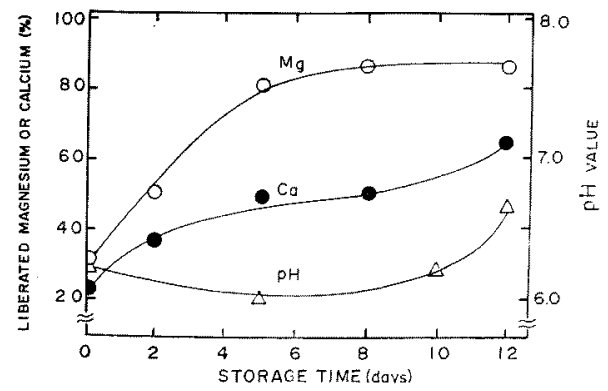

Fig. 2. Liberation of magnesium and calcium from the squid muscle proteins during storage at $4^{\circ} \mathrm{C}$.

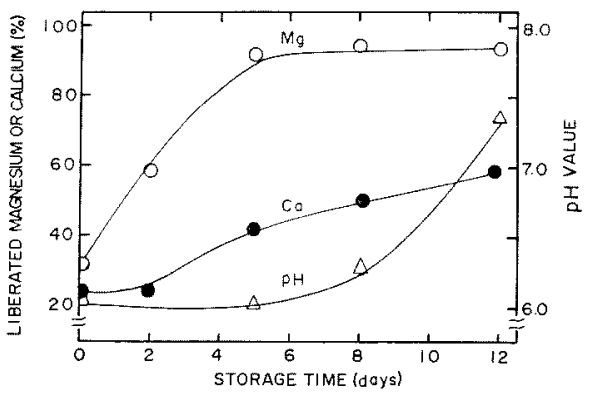

Fig. 3. Liberation of magnesium and calcium from the mackerel muscle proteins during storage at $4^{\circ} \mathrm{C}$. 
mation coincides well with the present results.

Intracellular distribution of magnesium. To know the fundamental aspects of localization of bound magnesium within the muscle cells, the centrifugal fractionation of carp muscle was carried out.

As shown in Table 3, the amount of dialysable magnesium was about $20 \%$ of the total amount, and the undialysable one was present in all the fractions.

Table 3. Intracellular distribution of magnesium in the carp muscle.

\begin{tabular}{|c|c|c|c|}
\hline \multirow[b]{2}{*}{ Fraction } & \multicolumn{2}{|c|}{ Magnesium content } & \multirow{2}{*}{$\underset{(\%)}{\text { Recovery }}$} \\
\hline & $\underset{(/ \mathrm{g} / \mathrm{mg} \text { protein- } \mathrm{N})}{\text { Relive }}$ & $\begin{array}{l}\text { Total } \\
(\mu \mathrm{g})\end{array}$ & \\
\hline Homogenate & 12.7 & & \\
\hline Dialysed preparation & 10.3 & 4,670 & 100 \\
\hline Precipitate $\quad 600 \times \mathrm{g}, 5 \mathrm{~min}$ & 6.0 & 2,760 & 59 \\
\hline $3,500 \times \mathrm{g}, 10 \mathrm{~min}$ & 8.7 & 690 & 15 \\
\hline $10,000 \times \mathrm{g}, 30 \mathrm{~min}$ & 114 & 118 & 3 \\
\hline Supernatant $10,000 \times \mathrm{g}, 30 \mathrm{~min}$ & 5.2 & 404 & 9 \\
\hline
\end{tabular}

These results appear to show that most of the cellular magnesium is substantially in complexes with protein, and that this magnesium would play an important role for biochemical reactions within the various sub-cellular particles of the muscle. This seems entirely plausible, since there are a number of enzymes which are activated by magnesium. It was further found that the fraction precipitating at $600 \times \mathrm{g}$ for 5 min contained more than half of the total amount of magnesium. Therefore, it might be important to know the binding aspects of protein with magnesium in this fraction. The further study on the interaction between protein and magnesium is now being attempted.

\section{Summary}

(1) The content of magnesium and calcium in the various tissues of fish and squid were determined by the atomic absorption spectrophotometry. The results showed that the contents were $4-36 \mathrm{mg} \%$ in calcium and $10-41 \mathrm{mg} \%$ in magnesium. The highest content of magnesium was found in the dorsal muscle in all the species of fish examined.

(2) On the liberation of magnesium and calcium from the muscle proteins, the chelating agency was postulated to become weaker immediately after the storage, as judged by the increment of the amount liberated.

(3) Centrifugal fractionation of the carp muscle homogenate revealed that the cellular magnesium was present in all the particles fractionated.

\section{References}

1) J. B. Willis: Anal. Chem., 33, 556-559(1961). 
2) J. B. Chappel and S. V. Perry: Biochem. J., 55, 586-595 (1953).

3) I. OsaKabe and K. SuzuKr: J. Tokyo Univ. Fish., 52, 47-60 (1966).

4) I. Osakabe and K. SuzuKi: ibid., 52, 135-144 (1966).

5) K. SuzUKI and I. Osakabe: ibid., 53, 53-63 (1967).

6) K. Suzuki and I. OsaKABE: The Canners J., 46, 53-56 (1967). 